\title{
Positive surgical margin following radical nephrectomy is an independent predictor of local recurrence and disease-specific survival
}

Yasmin Abu-Ghanem", Jacob Ramon ${ }^{1}$, Raanan Berger², Issac Kaver ${ }^{1}$, Edi Fridman ${ }^{3,4}$, Raya Leibowitz-Amit ${ }^{2}$ and Zohar A. Dotan ${ }^{1}$

\begin{abstract}
Background: Positive surgical margins (PSM) are recognized as an adverse prognostic sign and are often associated with higher rates of local and systemic disease recurrence. The data regarding the oncological outcome for PSM following radical nephrectomy (RN) is limited. We examined the predictive factors for PSM and its influence on survival and site of recurrence in patients treated with RN for renal cell carcinoma (RCC).

Methods: Clinical, pathologic and follow-up data on 714 patients undergoing RN for kidney cancer were analyzed. Secondary analysis included 44 patients with metastatic RCC upon diagnosis who underwent cytoreductive nephrectomy (CRN). Univariate and multivariable logistic regression models were fit to determine clinicopathologic features associated with PSM. A Cox proportional-hazards regression model was used to test the independent effects of clinical and pathologic variables on survival.

Results: PSM was documented in 17 cases (2.4\%). PSM were associated with tumour size, advanced pathologic stage (pT3 vs. $\leq$ pT2) and presence of necrosis. On multivariate analysis, cancer-specific survival (CSS) was associated with tumour stage, size, presence of necrosis and PSM. PSM was also associated with local recurrence but not distant metastasis or overall survival (OS). CSS and OS were comparable between the PSM and metastatic RCC groups, but significantly lower than the negative margin group.

Conclusions: The prevalence of PSM following RN is rare. Pathological data, including advanced stage (> pT2), tumour necrosis and tumour size, are associated with the presence of PSM. PSM is associated with tumour recurrence and CSS. Patients with PSM are a potential group for adjuvant therapy or for more careful and thorough follow-up following surgery.
\end{abstract}

Keywords: Positive surgical margins, Radical nephrectomy, Renal cell carcinoma, Recurrence, progression and overall mortality, Disease-specific mortality

\section{Background}

Positive surgical margins (PSM) are uniformly considered an adverse outcome associated with incomplete cancer removal and are often allied with increased risk of local or distant recurrence [1-3].

The management of patients with PSM remains a challenge in renal cell carcinoma (RCC) patients, with

\footnotetext{
* Correspondence: ag.yasmin@gmail.com

'Department of Urology, Sheba Medical Center, Ramat Gan, Israel

Full list of author information is available at the end of the article
}

controversy persisting over the need for more rigorous follow-up or for immediate adjunctive therapy. Over the past years, many studies have investigated the outcomes of patients reported to have a PSM following partial nephrectomy (PN). However, a consensus has yet to be reached on the prognostic significance and optimal management of these patients, in comparison to patients with negative surgical margins [4,5]. During the last decade, PN has become the standard of care for small exophytic, and favourably located renal tumours, based 
on its provision of equivalent cancer control and better preservation of long-term renal function. However, radical nephrectomy (RN) remains a commonly performed surgery, primarily in the cases in which partial resection is not feasible due to unfavourable tumour location or in patients with locally advanced tumour growth [6]. The data regarding the oncological outcome for PSM following radical nephrectomy is limited.

In the current study, we examined the potential predictors of PSM following RN and investigated long-term oncological outcomes in cases of PSM.

\section{Methods}

Data included all patients who underwent elective radical nephrectomy for renal masses between 1988 and 2013. Patient demographics and surgical details were collected retrospectively following an approval given by our Institutional Review Board. Informed consent was impossible or impracticable to obtain for such research. Research was done only after consideration and approval of a research ethics committee.

Clinical variables recorded included age, gender and co-morbidities. Tumour-related variables included tumour size, side and multifocality. Surgical variables included type of operation (i.e. open or laparoscopic). Pathological variables included capsular invasion, vascular invasion (including renal vein and inferior vena cava), renal pelvis invasion, perinephric fat extension and tumour necrosis.
Tumour stage was coded as a dichotomous variable, pT2 or lower vs. pT3. Data pertaining to tumour location or percent parenchyma involvement were unavailable for the majority of patients and were not included.

Patients with benign histology (including metanephric adenomas, angiomyolipomas and oncocytomas) were excluded from this analysis. Additional exclusion criteria included patients with malignant tumours other than renal cell carcinoma (urothelial cell carcinoma, sarcoma, neuroendocrine tumour, squamous cell carcinoma, leiomyoma and liposarcoma) or metastatic disease upon diagnosis (Fig. 1). Surgical margin status from the radical nephrectomy was recorded as positive or negative based on macroscopic and microscopic examination of the radical nephrectomy specimen. In all cases, the renal vein, renal vein margin and all other margins were examined grossly and sampled for microscopic examination if suspected of involvement. The interface between tumour and perinephric fat was sampled in all cases to evaluate perinephric fat invasion [7]. PSM were identified from pathology reports (determined by specialized pathologists), using the standard pathology criteria that define a PSM by either extension of tumour to the inked surface of the resected specimen on final pathology or evidence of tumour thrombus invasion into the segmental venous branch, renal vein or inferior vena cava. Tumour size was determined by measuring the maximal diameter of the tumour at pathological examination. Follow-up was

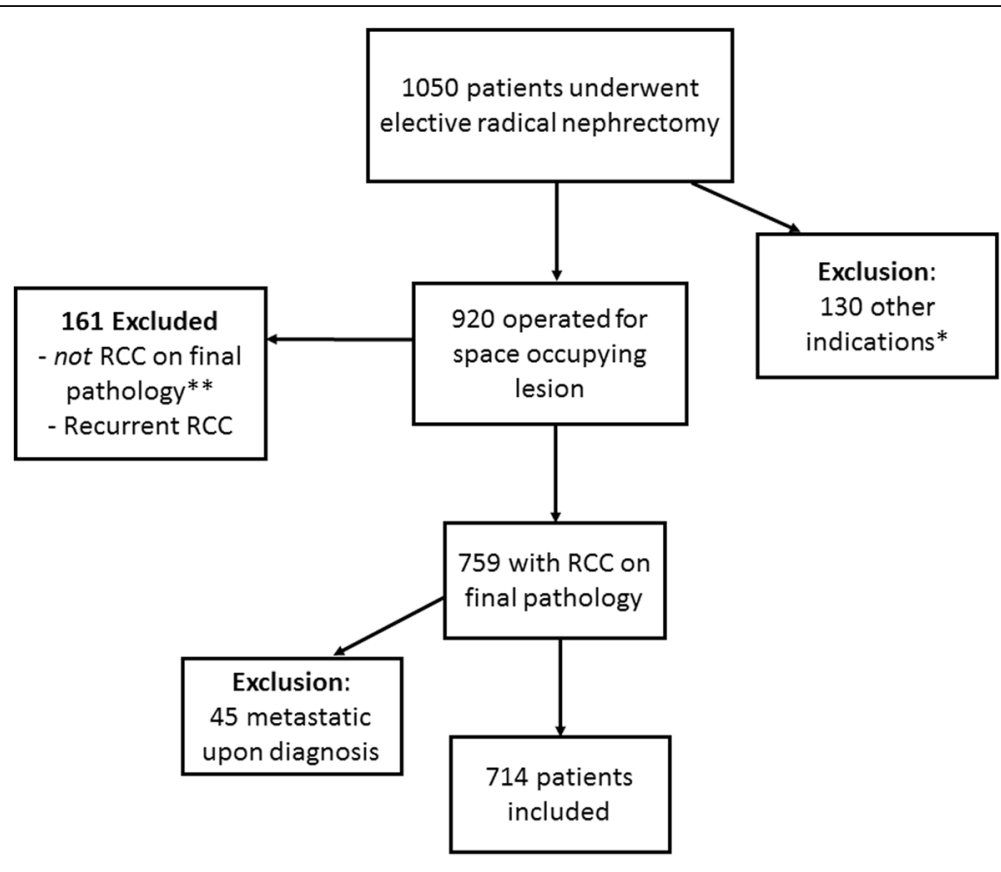

RCC $=$ renal cell carcinoma; ${ }^{*}=$ non functioning kidney, trauma, other; ${ }^{* *}=$ Transitional cell carcinoma (TCC), angiomyolipoma (AML), oncocytomas, other.

Fig. 1 Enrolment and eligibility of subjects who underwent radical nephrectomy between the years 1988 and 2013. 
conducted according to the standard clinical practice at our institution. In general, follow-up consisted of physical examination, chest radiographs and kidney imaging every 6 to 12 months during the first 5 years and annually thereafter. Patients with PSM on final pathology were observed at similar intervals with serial imaging. None of the patients was treated with immediate adjuvant therapy. Metastatic progression was defined as unequivocal imaging findings indicative of distant organ involvement with or without a confirmatory diagnostic biopsy (based on the discretion of a multi-disciplinary team).

\section{Statistical analysis}

Our main aim was to assess the risk factors for PSM and evaluate cancer control. Univariate and multivariable logistic regression analyses were used to determine features associated with PSM.

Outcomes measured included recurrence-free survival (local and distant), cancer-specific survival (CSS) and overall survival (OS). Our secondary aim was to compare the long-term outcome of these two groups to patients who underwent cytoreductive nephrectomy (CRN) for the treatment of metastatic disease. Secondary analysis included 44 patients with metastatic RCC (mRCC) upon diagnosis who underwent $\mathrm{RN}$ to improve survival. All patients were operated in our institute during the same study period. mRCC patients were excluded from primary analysis. Survival curves were estimated using the Kaplan-Meier method, and differences were compared with the log-rank test $(P<0.05$ was considered statistically significant). Cox proportional-hazard regression models were used to evaluate the association of PSM with outcomes, controlling for clinicopathologic variables. A $P$ value $<0.05$ was considered statistically significant. Statistical analyses were performed using Statistical Package for Social Sciences (SPSS, Version 21.0, Chicago, IL, USA).

\section{Results}

This study included 714 patients. The clinicopathologic demographics for these patients are provided in Table 1. Of 714 patients, $17(2.4 \%)$ had positive surgical margins at RN. Univariate analysis revealed several variables potentially associated with PSM including tumour size $(P=0.001)$, advanced pathologic stage $(P=0.001)$, central location $(P=0.01)$, tumour necrosis $(P=0.001)$ and capsular invasion $(P=0.002)$. Histologic RCC subtype and operative method (laparoscopic vs. open) were not associated with PSM (Table 2). All variables found significantly related to PSM in the univariate analysis were introduced into a multivariable logistic regression analysis. On multivariate analysis, tumour size $(P=0.001)$, presence of necrosis $(P=0.002)$ and advanced tumour stage
Table 1 Clinicopathologic demographics of 714 patients included in the study

\begin{tabular}{|c|c|c|}
\hline Variable & №. (\%) & $\mathrm{IQR}$ \\
\hline Age (years) & $63.1 \pm 12.9$ & $55-72$ \\
\hline \multicolumn{3}{|l|}{ Gender } \\
\hline $\begin{array}{l}\text { Male } \\
\text { Female }\end{array}$ & $\begin{array}{l}439(61) \\
275(39)\end{array}$ & \\
\hline \multicolumn{3}{|l|}{ Co-morbidities } \\
\hline $\begin{array}{l}\text { HTN } \\
\text { DM } \\
\text { Hyperlipidemia } \\
\text { IHD } \\
\text { Smoking }\end{array}$ & $\begin{array}{l}149(21) \\
43(6) \\
24(3) \\
43(6) \\
131(18)\end{array}$ & \\
\hline Central renal lesion & $124(17)$ & \\
\hline Tumour size (cm) & $6.7 \pm 3.1$ & $4.5-8$ \\
\hline \multicolumn{3}{|l|}{ Operative method } \\
\hline $\begin{array}{l}\text { Open } \\
\text { Lap }\end{array}$ & $\begin{array}{l}481(67) \\
233(33)\end{array}$ & \\
\hline Positive surgical margins & $17(2.4)$ & \\
\hline \multicolumn{3}{|l|}{ Pathology } \\
\hline $\begin{array}{l}\text { Necrotic tumour } \\
\text { Capsular invasion }\end{array}$ & $\begin{array}{l}207(29.0) \\
132(19)\end{array}$ & \\
\hline \multicolumn{3}{|l|}{ Tumour stage } \\
\hline $\begin{array}{l}\leq \mathrm{T} 2 \\
\geq \mathrm{T} 3\end{array}$ & $\begin{array}{l}440(62) \\
274(38)\end{array}$ & \\
\hline \multicolumn{3}{|l|}{ Nuclear grade } \\
\hline $\begin{array}{l}1 \\
2 \\
3 \\
4\end{array}$ & $\begin{array}{l}50(7) \\
335(47) \\
250(35) \\
78(11)\end{array}$ & \\
\hline \multicolumn{3}{|l|}{ RCC type } \\
\hline $\begin{array}{l}\text { Clear cell } \\
\text { Chromophobe } \\
\text { Papillary } \\
\text { Other } \\
\text { Unknown }\end{array}$ & $\begin{array}{l}496(69) \\
44(6) \\
70(10) \\
14(2) \\
90(13)\end{array}$ & \\
\hline
\end{tabular}

Values in parentheses are percentages; continuous variables are presented as (mean $\pm \mathrm{sd}$ )

Abbreviations: $R C C$ renal cell carcinoma

$(P=0.002)$ remained significantly associated with PSM (Table 3).

\section{Survival analysis--univariate}

Of the study cohort, 102 (14.3\%) were lost to follow-up. Survival analysis was done for the remaining 612 . The overall median follow-up was 65 months (IQR 27-120). Fifty-three percent of the patients were followed for more than 5 years, and $24.3 \%$ of the patients were followed for 10 years and more. There were 50 local recurrence events, and 92 patients developed metastatic progression. Thirtysix (38.3\%) of the patients with metastatic progression had previously experienced a local recurrence. The overall 5and 10-year freedom from local disease recurrence was 91\% (95\% CI 90, 92) and 89\% (95\% CI 91, 93), respectively, 
Table 2 Univariate analysis of predictive factors for positive surgical margins among patients undergoing radical nephrectomy for renal masses

\begin{tabular}{|c|c|c|c|}
\hline Variable & No PSM, $n=697$ & $\mathrm{PSM}, n=17$ & $P$ value \\
\hline Age & $63.0 \pm 12.8$ & $66.7 \pm 15$ & 0.43 \\
\hline Gender & & & 0.82 \\
\hline $\begin{array}{l}\text { Male } \\
\text { Female }\end{array}$ & $\begin{array}{l}429(61) \\
268(39)\end{array}$ & $\begin{array}{l}10(59) \\
8(41)\end{array}$ & \\
\hline \multicolumn{4}{|l|}{ Co-morbidities } \\
\hline $\begin{array}{l}\text { HTN } \\
\text { DM } \\
\text { Hyperlipidemia } \\
\text { IHD } \\
\text { Smoking }\end{array}$ & $\begin{array}{l}142(20) \\
42(6) \\
24(3) \\
40(6) \\
128(18)\end{array}$ & $\begin{array}{l}7(41) \\
1(6) \\
0(0) \\
3(15) \\
3(18)\end{array}$ & $\begin{array}{l}0.04 \\
0.98 \\
0.44 \\
0.04 \\
0.94\end{array}$ \\
\hline Central renal lesion & $117(16.8)$ & $7(41.2)$ & 0.01 \\
\hline Tumour size & & & 0.01 \\
\hline $\begin{array}{l}\leq 7 \mathrm{~cm} \\
>7 \mathrm{~cm}\end{array}$ & $\begin{array}{l}419(60.1) \\
278(39.9)\end{array}$ & $\begin{array}{l}6(35) \\
11(65)\end{array}$ & \\
\hline Nuclear grade & & & 0.08 \\
\hline $\begin{array}{l}1 \\
2 \\
3 \\
4\end{array}$ & $\begin{array}{l}50(7) \\
325(47) \\
243(35) \\
78(11)\end{array}$ & $\begin{array}{l}0(0) \\
10(59) \\
7(41) \\
0(0)\end{array}$ & \\
\hline Operative method & & & 0.6 \\
\hline $\begin{array}{l}\text { Open } \\
\text { Lap }\end{array}$ & $\begin{array}{l}446(67) \\
231(33)\end{array}$ & $\begin{array}{l}15(88) \\
2(12)\end{array}$ & \\
\hline \multicolumn{4}{|l|}{ Pathology } \\
\hline $\begin{array}{l}\text { Necrotic tumour } \\
\text { Capsular invasion }\end{array}$ & $\begin{array}{l}193(28) \\
124(18)\end{array}$ & $\begin{array}{l}14(82) \\
8(47)\end{array}$ & $\begin{array}{l}0.001 \\
0.002\end{array}$ \\
\hline Tumour stage & & & 0.001 \\
\hline $\begin{array}{l}\leq \mathrm{T} 2 \\
\geq \mathrm{T} 3\end{array}$ & $\begin{array}{l}440(63) \\
257(37)\end{array}$ & $\begin{array}{l}0(0) \\
17(100)\end{array}$ & \\
\hline RCC type & & & 0.26 \\
\hline $\begin{array}{l}\text { Clear cell } \\
\text { Chromophobe } \\
\text { Papillary } \\
\text { Other }\end{array}$ & $\begin{array}{l}483(80) \\
44(7) \\
66(11) \\
14(2)\end{array}$ & $\begin{array}{l}13(76) \\
0(0) \\
4(24) \\
0(0)\end{array}$ & \\
\hline
\end{tabular}

Values in parentheses are percentages; continuous variables are presented as (mean $\pm \mathrm{sd}$ )

Abbreviations: PSM positive surgical margins, RCC renal cell carcinoma

and freedom from metastatic progression was 84\% (95\% CI 82,86$)$ and $81 \%(95 \%$ CI 79, 83), respectively. PSM was associated with significantly worse 5 -year freedom from local recurrence (93\% compared with $45 \% ; P<0.001$ ) and 5 -year freedom from metastatic progression (85 vs. $32 \%$;

Table 3 Multivariate analysis of the statistically significant predictive factors for positive surgical margins among patients undergoing radical nephrectomy for renal masses

\begin{tabular}{llll}
\hline Variable & HR & $95 \% \mathrm{Cl}$ & $P$ value \\
\hline Tumour size & 0.4 & $0.4-0.5$ & 0.001 \\
Tumour necrosis & 5.0 & $1.8-14$ & 0.002 \\
Tumour stage (pT3-4 compared with pT1-T2) & 5.5 & $1.9-15.9$ & 0.002 \\
\hline
\end{tabular}

Abbreviations: $\mathrm{HR}$ hazard ratio, $\mathrm{Cl}$ confidence interval
$P<0.001)$. Similarly, patients with PSM had adverse 5year CSS ( 90 vs. $41 \% ; P<0.001)$ as well as adverse OS (73 vs. $37 \% ; P<0.001)$.

\section{Survival analysis--multivariate}

We next assessed the association of PSM with outcome, controlling for patient and tumour-related variables (Table 4). We found that PSM remained associated with significantly increased risks of local tumour recurrence (hazard ratio (HR); 4.8, 95\% CI 2-11.6, $P=0.01$ ) and death from RCC (HR 2.4; 95\% CI 1.1-5.5, $P=0.03$ ). PSM did not affect the rate of metastatic progression or all-cause mortality. The last was associated with patient's age (HR 1.03; 95\% CI 1.01-1.04, $P=0.003$ ), tumour stage (HR 2.2; 95\% CI 1.4-3.5, $P=0.001$ ) and presence of tumour necrosis (HR 2.0; 95\% CI 1.3-2.9, $P=0.001$ ). Tumour necrosis (HR 2.2; 95\% CI 1.2-4.0, $P=0.01$ ) was also associated with increased risks of death from RCC along with advanced pathologic tumour stage (HR 4.2; 95\% CI 1.9-9.1, $P=0.001$ ) and size (HR 1.1; 95\% CI $1.02-1.2, P=0.01$ ).

\section{PSM vs. metastatic disease}

Given the poor prognosis of patients with PSM, we next examined whether their oncologic outcomes match those with metastatic disease upon diagnosis (undergoing cytoreductive surgery). Forty-five patients with metastatic RCC who underwent RN were included. All patients in this group had been excluded from the previous analysis.

The subgroup analysis included three groups: nonmetastatic, no PSM $(n=697)$, non-metastatic, PSM $(n=17)$ and metastatic $(n=45)$.

According to the Kaplan-Meier analysis, median OS was significantly higher in the negative surgical margin group in comparison to both PSM (154 vs. 31.6 months, HR 2.8, 95\% CI 2.1 to $14.7, P<0.01)$ and metastatic group (154 vs.14.3 months, HR 4, 95\% CI 7.9 to 30.3, $P<0.01)$. Yet, no differences were found between the PSM and metastatic groups in terms of OS (Fig. 2). Similarly, CSS was found to be significantly poorer in the metastatic group compared to patients with a negative margin (median CSS 16.3 vs. 175.5 months, respectively; $P=0.001)$. Yet, no differences were observed between the metastatic and the PSM groups (Fig. 3).

\section{Discussion}

The achievement of negative surgical margins has a paramount importance and remains the main goal during oncologic surgery. PSM is recognized as an adverse prognostic sign for disease recurrence, especially in tumours of high malignant potential. The potential unfavourable effect of PSM on disease progression and CSS has been previously described in different types of 
Table 4 Multivariate analysis of factors associated with tumour recurrence, death from renal cancer and all-cause mortality following radical nephrectomy

\begin{tabular}{|c|c|c|c|c|c|c|}
\hline \multirow{3}{*}{ Variable } & \multirow{2}{*}{\multicolumn{3}{|c|}{ Local recurrence }} & \multirow{2}{*}{\multicolumn{3}{|c|}{ Metastatic progression }} \\
\hline & & & & & & \\
\hline & $H R$ & $95 \% \mathrm{Cl}$ & $P$ value & $H R$ & $95 \% \mathrm{Cl}$ & $P$ value \\
\hline Age & 0.99 & $0.97-1.01$ & 0.3 & 0.99 & $0.97-1.0$ & 0.2 \\
\hline Gender & 0.75 & $0.4-1.4$ & 0.4 & 1.0 & $0.6-1.6$ & 0.99 \\
\hline Tumour size & 1.1 & $0.99-1.2$ & 0.06 & 1.1 & $1.0-1.1$ & 0.03 \\
\hline Central renal lesion & 1.0 & $0.5-2.2$ & 0.9 & 0.97 & $0.5-1.8$ & 0.92 \\
\hline Positive surgical margins & 4.8 & $2-11.6$ & 0.001 & 2.1 & $0.96-4.4$ & 0.06 \\
\hline \multicolumn{7}{|l|}{ Pathology } \\
\hline $\begin{array}{l}\text { Necrotic tumour } \\
\text { Capsular invasion }\end{array}$ & $\begin{array}{l}1.1 \\
2.1\end{array}$ & $\begin{array}{l}0.6-2.2 \\
1.1-4.2\end{array}$ & $\begin{array}{l}0.7 \\
0.03\end{array}$ & $\begin{array}{l}2.3 \\
1.4\end{array}$ & $\begin{array}{l}1.3-3.8 \\
0.8-2.4\end{array}$ & $\begin{array}{l}0.001 \\
0.2\end{array}$ \\
\hline Tumour stage (pT3-4 compared with pT1-T2) & 3.1 & $1.4-7$ & 0.005 & 3.6 & $2.0-6.5$ & 0.001 \\
\hline \multirow[t]{2}{*}{ Variable } & \multicolumn{3}{|c|}{ All-cause mortality } & \multicolumn{3}{|c|}{ Disease-specific mortality } \\
\hline & $H R$ & $95 \% \mathrm{Cl}$ & $P$ value & $H R$ & $95 \% \mathrm{Cl}$ & $P$ value \\
\hline Age & 1.03 & $1.01-1.04$ & 0.003 & 1.0 & $0.98-1.02$ & 0.99 \\
\hline Gender & 0.8 & $0.6-1.2$ & 0.3 & 0.9 & $0.5-1.6$ & 0.6 \\
\hline Tumour size & 1.05 & $0.99-1.1$ & 0.1 & 1.1 & $1.02-1.2$ & 0.01 \\
\hline Central renal lesion & 0.7 & $0.4-1.2$ & 0.3 & 0.7 & $0.3-1.5$ & 0.37 \\
\hline Positive surgical margins & 1.3 & $0.6-2.9$ & 0.5 & 2.4 & $1.1-5.5$ & 0.03 \\
\hline \multicolumn{7}{|l|}{ Pathology } \\
\hline $\begin{array}{l}\text { Necrotic tumour } \\
\text { Capsular invasion }\end{array}$ & $\begin{array}{l}2.0 \\
1.3\end{array}$ & $\begin{array}{l}1.3-2.9 \\
0.8-1.9\end{array}$ & $\begin{array}{l}0.001 \\
0.2\end{array}$ & $\begin{array}{l}2.2 \\
1.9\end{array}$ & $\begin{array}{l}1.2-4.0 \\
1.0-3.5\end{array}$ & $\begin{array}{l}0.01 \\
0.05\end{array}$ \\
\hline Tumour stage (pT3-T4 compared with pT1-T2) & 2.2 & $1.4-3.5$ & 0.001 & 4.2 & $1.9-9.1$ & 0.001 \\
\hline
\end{tabular}

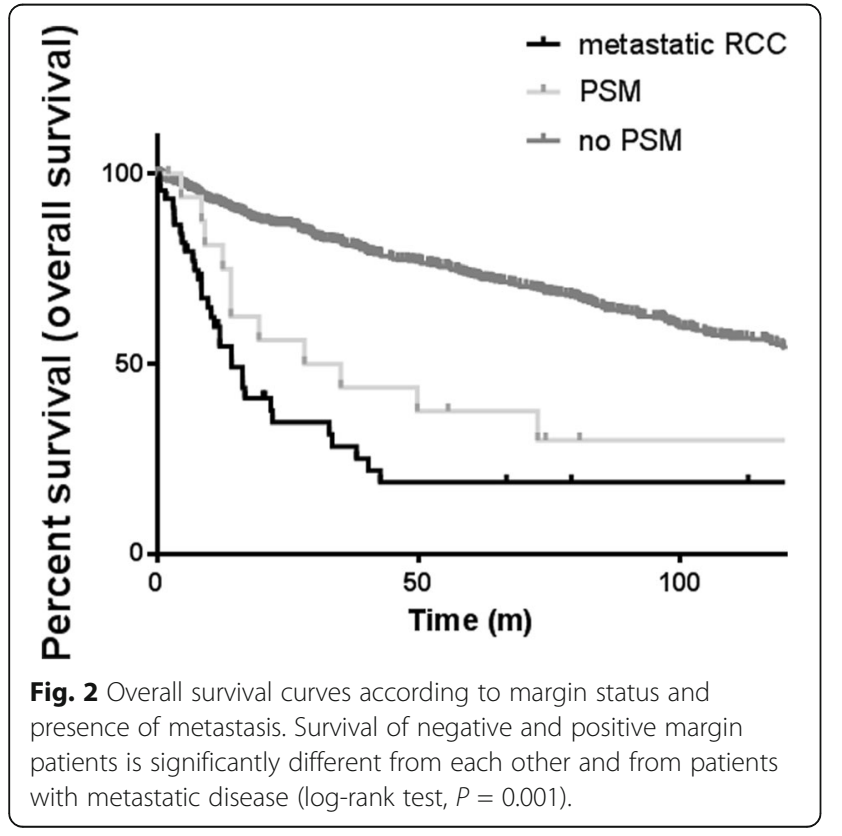

tumours including prostate, rectal and breast cancer but not for renal cancer [8-12].

In recent years, large series have analyzed the preoperative risk factors for PSM after PN. Several factors have been advocated as predictors, such as older age, tumour size, location, pathological stage, Fuhrman grade and indication (elective vs. imperative) [5, 13-15]. Correspondingly, conflicting evidence has accumulated on whether PSM is also a significant risk factor for disease progression, while large-scale studies like Yossepowitch et al., Lopez-Costea et al. or Antic et al. suggest no correlation between PSM and local recurrence or distant progression [14, 16, 17]. Other investigators such as Kwon et al. and Bernhard et al. $[18,19]$ identified PSM as an independent risk factor for tumour recurrence in the setting of partial nephrectomy, though CSS and OS were not affected by margin status. Yet, despite this discordance, the main implication regarding disease recurrence rate for PSM in partial nephrectomy is the postoperative management. In lieu of the adverse outcome associated with PSM in other solid tumours, patients with PSM should be offered all therapeutic options including radical nephrectomy, repeat $\mathrm{PN}$, energy ablation and vigilant observation [4, 20-22]. 


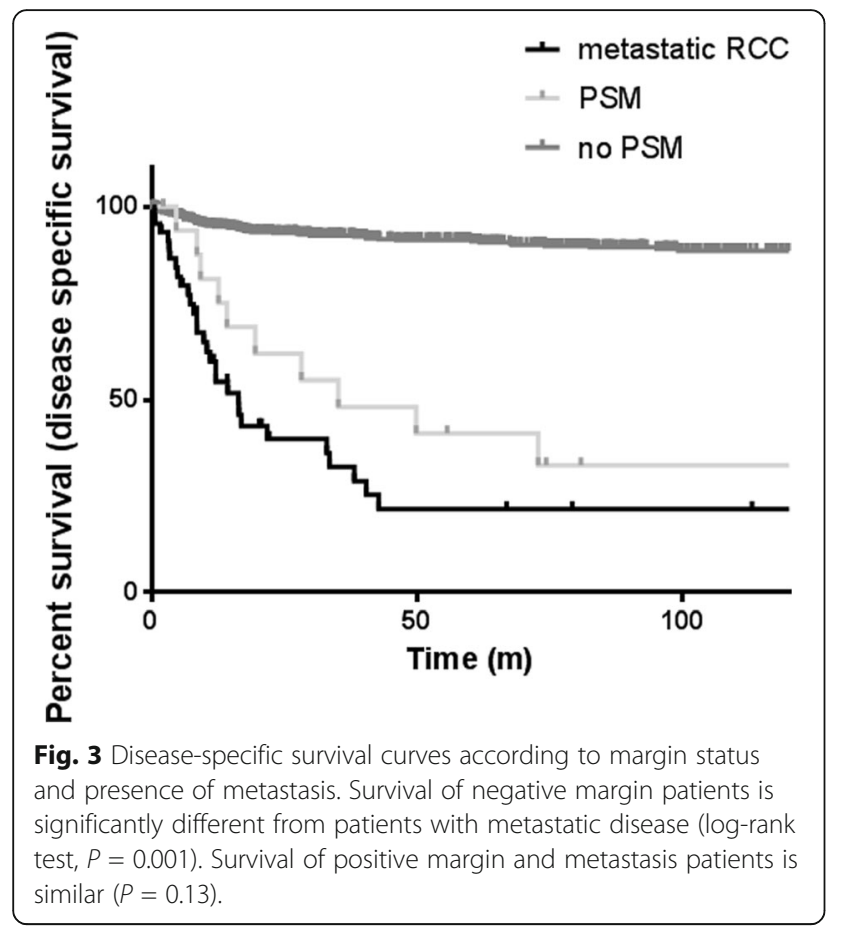

Considering the conclusions outlined, it indicates that although the prognostic impact of PSM after PN is ambiguous, these patients should still be closely monitored. Hence, the arising question is whether this conclusion can be applied for patients who undergo radical nephrectomy. To date, PN has been considered the standard of care for the treatment of most renal tumours, with long-term oncologic results equivalent to those of RN. However, PN is unsuitable in some patients with localized RCC due to locally advanced tumour growth or unfeasible because of unfavourable tumour location or significant deterioration in patient health [6]. Thus, the predictive factors for PSM following RN and its implication on patients' follow-up are a matter of interest. In the current study, positive margins were associated with pathologic stage ( $\leq \mathrm{pT} 2$ vs. pT3), tumour size and tumour necrosis. Increased pathological stage is associated with positive surgical margin in other malignancies treated surgically such as prostate, bladder and oral cavity cancer [23-25]. According to the current paper, we have demonstrated the association between locally advanced disease (pathological stage ( $\leq$ pT2 vs. pT3)) and the presence of PSM. In addition, vascular involvement and tumour necrosis are associated with adverse oncology outcomes in renal cancer and therefore were found to be associated with PSM in addition to pathological stage by multivariate analysis.

In regard to oncologic outcome, previous studies have reported different factors to predict survival after RN, including tumour stage, size, grade and necrosis [7]. An earlier study by Leibovich et al. [26] has reviewed the prediction of progression after $\mathrm{RN}$ for patients with clear cell RCC. In his study, Leibovich and colleagues presented a rate of $0.7 \%$ PSM. Univariate analysis revealed significant association between PSM and metastasis, yet this factor did not remain significant in a multivariate modeling. Frank et al.[7] presented similar results, including the rate of PSM (0.8\%). However, given the small number of cases, Frank and colleagues chose to exclude PSM from further analysis. In the current study, PSM is documented in 17 cases (2.4\%). These differences in PSM proportions should be attributed to the predisposing tumour properties. Although tumour size was comparable between the studies, nearly $40 \%$ of the patients in the current study had pathologic stage of $\mathrm{T} 3$ and more, in comparison to 36 and $31 \%$ presented by Frank et al. and Leibovich et al., respectively. Moreover, no data is available on the rate of vascular invasion, which is also found to be a significant risk factor for PSM. Finally, both studies conducted analysis only on patients with clear cell RCC, which may have created a selection bias [14].

Our study showed, using multivariable analysis, that the only factor that could predict local recurrence was PSM. In parallel with Leibovich et al., PSM was not associated with metastatic rate, yet tumour necrosis, size and stage could predict metastatic progression. PSM was also associated with CSS along with tumour necrosis and stage, yet not with OS. Further analysis revealed that the effect on survival is so profound that patients with PSM have similar median survival rate to those with metastatic disease upon diagnosis. These results suggest that patients with positive SM, particularly with advanced tumour stage, should be offered more appropriate postoperative surveillance programs, including close monitoring. Currently, we cannot address the role of adjuvant therapy in order to improve the rate of local recurrence, metastasis or cancer-specific survival, due to lack of data to support it. In future, studies that will address the role of adjuvant therapy for high-risk renal cancer following radical nephrectomy should be stratified according to the status of SM.

Our study is not without limitations. First, this study is retrospective, with the entire attendant imprecision associated with the large recollection of data. Second, the number of patients with PSM is small. We acknowledge the fact that 17 patients is a small number; however, giving the potential effect on patients' outcome and prognosis, analysis of this group, despite its small number, is rather important. To date, the literature relating to this subject is limited, specifically in regard to the association between PSM (following RN) and prognosis. To our knowledge, the current study is the first to directly investigate this association and suggest on its clinical implications. Despite the relatively small number and its 
limitations, being a retrospective study, we believe that such findings would encourage future randomized clinical trials and will shed the necessary focus on this important entity.

\section{Conclusion}

In this study, we defined the clinical significance of a PSM after RN for RCC. Resection margin appears to be an independent predictor of local recurrence-free and diseasespecific survival for all patient subsets. Knowledge of the risk factors for PSM and its influence on disease progression may help clinicians to assess the effects of tumour characteristics on the oncological outcomes following radical nephrectomy, which can be used to improve treatment. The results of this study underscore the significance of histologic resection margin as a prognostic factor after RN.

Future randomized clinical trials are required before we could confirm that the higher incidence rate of PSM does translate into a poorer survival rate.

\section{Abbreviations}

RCC: Renal cell carcinoma; PSM: Positive surgical margins; RN: Radical nephrectomy; PN: Partial nephrectomy; CRN: Cytoreductive nephrectomy; CSS: Cancer-specific survival; OS: Overall survival

\section{Acknowledgements}

None.

\section{Funding}

None

\section{Availability of data and materials}

Our data will not be shared temporarily because the data will be used in an additional study about RCC.

\section{Authors' contributions}

YAG collected and interpreted the data. YAG and ZD designed and edited the manuscript of the study. JR, RB, IK, EF and RLA drafted the manuscript. All authors read and approved the final manuscript.

\section{Ethics approval and consent to participate}

Patient demographics and surgical details were collected retrospectively following an approval given by our Institutional Review Board. Informed consent was impossible or impracticable to obtain for such research. Research was done only after consideration and approval of a research ethics committee.

\section{Consent for publication}

Not applicable.

\section{Competing interests}

The authors declare that they have no competing interests.

\section{Publisher's Note}

Springer Nature remains neutral with regard to jurisdictional claims in published maps and institutional affiliations.

\section{Author details}

'Department of Urology, Sheba Medical Center, Ramat Gan, Israel. 2Department of Oncology, Sheba Medical Center, Ramat Gan, Israel. ${ }^{3}$ Department of Pathology, Sheba Medical Center, Ramat Gan, Israel. ${ }^{4}$ Sackler Faculty of Medicine, Tel Aviv University, Tel Aviv, Israel.
Received: 2 September 2017 Accepted: 15 October 2017

Published online: 02 November 2017

\section{References}

1. Grossfeld GD, Chang JJ, Broering JM, Miller DP, Yu j, Flanders SC, Henning JM, Stier DM, Carroll PR. Impact of positive surgical margins on prostate cancer recurrence and the use of secondary cancer treatment: data from the capsure database. J Urol. 2000;163(4):1171-7.

2. Phang PT, Macfarlane JK, Taylor RH, Cheifetz RE, Davis N, Hay JH, Mcgregor G, Speers C, Sullivan BJ, Pitts J, Coldman AJ. Effects of positive resection margin and tumor distance from anus on rectal cancer treatment outcomes. Am J Surg. May 2002;183(5):504-8.

3. Pawlik TM, Scoggins CR, Zorzi D, Abdalla EK, Andres A, Eng C, Curley SA, Loyer EM, Muratore A, Mentha G, Capussotti L, Vauthey J-N. Effect of surgical margin status on survival and site of recurrence after hepatic resection for colorectal metastases. Ann Surg. 2005;241(5):715-722, NaN-4.

4. M. Marszalek, M. Carini, P. Chlosta, K. Jeschke, Z. Kirkali, S. Madersbacher, J. Patard, H. Van Poppel, and R. Knu, Positive surgical margins after nephronsparing surgery, vol. 61, pp. 757-763, 2012.

5. Bensalah K, Pantuck AJ, Rioux-Leclercq N, Thuret R, Montorsi F, Karakiewicz PI, Mottet N, Zini L, Bertini R, Salomon L, Villers A, Soulie M, Bellec L, Rischmann P, De la Taille A, Avakian R, Crepel M, Ferriere J-M, Bernhard J-C, Dujardin T, Pouliot F, Rigaud J, Pfister C, Albouy B, Guy L, Joniau S, van Poppel H, Lebret T, Culty T, Saint F, Zisman A, Raz O, Lang H, Spie R, Wille A, Roigas J, Aguilera A, Rambeaud B, Martinez Piñeiro L, Nativ O, Farfara R, Richard F, Roupret M, Doehn C, Bastian PJ, Muller SC, Tostain J, Belldegrun AS, Patard J-J. Positive surgical margin appears to have negligible impact on survival of renal cell carcinomas treated by nephron-sparing surgery. Eur Urol. 2010;57(3):466-71.

6. B. Ljungberg, K. Bensalah, A. B. Vice-chair, S. Canfield, S. D. G. Associate, R. H. G. P. Advocate, L. M. G. Associate, and A. S. Merseburger, Guidelines on renal cell carcinoma, 2015.

7. FRANK I, BLUTE ML, CHEVILLE JC, LOHSE CM, WEAVER AL, ZINCKE H. An outcome prediction model for patients with clear cell renal cell carcinoma treated with radical nephrectomy based on tumor stage, size, grade and necrosis: the sign score. J Urol. 2002;168(6):2395-400.

8. de Haas-Kock DF, Baeten CG, Jager JJ, Langendijk JA, Schouten LJ, Volovics A, Arends JW. Prognostic significance of radial margins of clearance in rectal cancer. Br J Surg. 1996;83(6):781-5.

9. Meric F, Mirza NQ, Vlastos G, Buchholz TA, Kuerer HM, Babiera GV, Singletary SE, Ross MI, Ames FC, Feig BW, Krishnamurthy S, Perkins GH, McNeese MD, Strom EA, Valero V, Hunt KK. Positive surgical margins and ipsilateral breast tumor recurrence predict disease-specific survival after breast-conserving therapy. Cancer. 2003;97(4):926-33.

10. Adam IJ, Mohamdee MO, Martin IG, Scott N, Finan PJ, Johnston D, Dixon MF, Quirke P. Role of circumferential margin involvement in the local recurrence of rectal cancer. Lancet (London, England). 1994;344(8924):707-11.

11. Pfitzenmaier J, Pahernik S, Tremmel T, Haferkamp A, Buse S, Hohenfellner M. Positive surgical margins after radical prostatectomy: do they have an impact on biochemical or clinical progression? BJU Int. 2008;102(10):1413-8.

12. Wright JL, Dalkin BL, True LD, Ellis WJ, Stanford JL, Lange PH, Lin DW. Positive surgical margins at radical prostatectomy predict prostate cancer specific mortality. J Urol. 2010;183(6):2213-8.

13. Ani I, Finelli A, Alibhai SMH, Timilshina N, Fleshner N, Abouassaly R. Prevalence and impact on survival of positive surgical margins in partial nephrectomy for renal cell carcinoma: a population-based study. BJU Int 2013;111(8):E300-5.

14. Yossepowitch O, Thompson RH, Leibovich BC, Eggener SE, Pettus JA, Kwon ED, Herr HW, Blute ML, Russo P. Positive surgical margins at partial nephrectomy: predictors and oncological outcomes. J Urol. 2008;179(6):2158-63.

15. Schiavina R, Serni S, Mari A, Antonelli A, Bertolo R, Bianchi G, Brunocilla E, Borghesi M, Carini M, Longo N, Martorana G, Mirone V, Morgia G, Porpiglia F, Rocco B, Rovereto B, Simeone C, Sodano M, Terrone C, Ficarra V, Minervini A. A prospective, multicenter evaluation of predictive factors for positive surgical margins after nephron-sparing surgery for renal cell carcinoma: the RECORd1 Italian Project. Clin Genitourin Cancer. 2015;13(2):165-70.

16. Lopez-Costea MA, Fumadó L, Lorente D, Riera L, Miranda EF. Positive margins after nephron-sparing surgery for renal cell carcinoma: long-term follow-up of patients on active surveillance. BJU Int. 2010;106(5):645-8.

17. Antic T, Taxy JB. Partial nephrectomy for renal tumors: lack of correlation between margin status and local recurrence. Am J Clin Pathol. May 2015;143(5):645-51. 
18. Kwon EO, Carver BS, Snyder ME, Russo P. Impact of positive surgical margins in patients undergoing partial nephrectomy for renal cortical tumours. BJU Int. 2007;99(2):286-9.

19. Bernhard J-C, Pantuck AJ, Wallerand $H$, Crepel M, Ferrière J-M, Bellec L Maurice-Tison S, Robert G, Albouy B, Pasticier G, Soulie M, Lopes D, Lacroix B, Bensalah K, Pfister C, Thuret R, Tostain J, De La Taille A, Salomon L, Abbou C, Colombel M, Belldegrun AS, Patard J-J. Predictive factors for ipsilateral recurrence after nephron-sparing surgery in renal cell carcinoma. Eur Urol. 2010;57(6):1080-6.

20. Marszalek M, Meixl H, Polajnar M, Rauchenwald M, Jeschke K, Madersbacher S Laparoscopic and open partial nephrectomy: a matched-pair comparison of 200 patients. Eur Urol. 2009;55(5):1171-8.

21. Peycelon M, Hupertan V, Comperat E, Renard-Penna R, Vaessen C, Conort P, Bitker M-O, Chartier-Kastler E, Richard F, Rouprêt M. Long-term outcomes after nephron sparing surgery for renal cell carcinoma larger than $4 \mathrm{~cm}$. J Urol. 2009;181(1):35-41.

22. Sundaram V, Figenshau RS, Roytman TM, Kibel AS, Grubb RL, Bullock A, Benway BM, Bhayani SB. Positive margin during partial nephrectomy: does cancer remain in the renal remnant? Urology. 2011;77(6):1400-3.

23. Liss $\mathrm{M}$, Osann $\mathrm{K}$, Ornstein D. Positive surgical margins during robotic radical prostatectomy: a contemporary analysis of risk factors. BJU Int. 2008:102(5):603-8.

24. Luryi AL, Chen MM, Mehra S, Roman SA, Sosa JA, Judson BL. Positive surgical margins in early stage oral cavity cancer: an analysis of 20,602 cases. Otolaryngol Head Neck Surg. 2014;151(6):984-90.

25. Dotan ZA, Kavanagh K, Yossepowitch O, Kaag M, Olgac S, Donat M, Her HW. Positive surgical margins in soft tissue following radical cystectomy for bladder cancer and cancer specific survival. J Urol. 2007;178(6):2308-2312; Discussion 2313

26. Leibovich BC, Blute ML, Cheville JC, Lohse CM, Frank I, Kwon ED, Weaver AL, Parker AS, Zincke H. Prediction of progression after radical nephrectomy for patients with clear cell renal cell carcinoma: a stratification tool for prospective clinical trials. Cancer. 2003:97(7):1663-71.

\section{Submit your next manuscript to BioMed Central and we will help you at every step:}

- We accept pre-submission inquiries

- Our selector tool helps you to find the most relevant journal

- We provide round the clock customer support

- Convenient online submission

- Thorough peer review

- Inclusion in PubMed and all major indexing services

- Maximum visibility for your research

Submit your manuscript at www.biomedcentral.com/submit

) Biomed Central 